\title{
1876年フィラデルフィア万国博覧会の建築にみる「日本」 \\ ON THE STUDY OF THE 'JAPANESE' ELEMENTS IN THE HISTORICAL CONTEXT FROM THE ANALYSIS OF THE TWO JAPANESE BUILDINGS AT THE CENTENNIAL EXHIBITION IN 1876
}

\author{
畑 智子* \\ Tomoko HATA
}

\begin{abstract}
At the Centennial Exhibition in Philadelphia in 1876 Japanese carpenters built two buildings. Japanese Bazaar and Japanese Dwelling. Scrutinizing them from the historical context, it came to clear that the former was organized by the Japanese government with the intention of promoting export. and for it we can see the representation of 'traditional' Japanese elements.

It was one of the good examples of the Exhibition buildings for thinking about the representation of 'traditional' Japanese style or motifs in countries overseas.
\end{abstract}

Key words: International Exhibition, Policy of Promoting Industry, Philadelphia, Representation of 'Traditional' Style, early Meiji era 万国博覧会、殖産興業政策、フィラデルフィア、「伝統」の表出、明治初期、

序

19世紀の万国博覧会において日本人が建てた建築物についての研 究は、すでにいくつか報告されている1。しかし1876(明治9)年米国 のフィラデルフィアで行われた独立百年記念博覧会（以下フィラデ ルフィア博と記す）における日本人による建築物についての詳細な 研究は管見のかぎり見られない2)。日本側の資料が少ないせいか、 その事実さえ充分に明らかにはされていないようであるか。

しかし、本調查によって、フィラデルフィア博には日本人大工に よって本格的な二棟の建物が建てられたことが確認された。一棟は 日本政府によるJapanese Bazaar(売店)、もう一棟は金沢の河村幸 の出資によるJapanese Drelling(住宅家屋)である。本稿ではこれ らの二棟の分析を通して、そこに見られる「日本的なもの」とその 歴史的背景について考察したい。

また、この博覧会は、建築も含めて日本の文物が実質的にアメリ カの人々の目に触れた最初の機会でもあるれ。これ以後、アメリカ において擬日本様式の別荘建設も始まっており5、日本の工芸品を 扱うオークションも急速に增えている。アメリカで急速に広まる日 本の影響を考えるなら、アメリカと日本との関係におけるこの博覧 会の重要性はきわめて大きいと言えるだろう。

本稿は、日本の博覽会事務局による「米国博覧会報告書」邓、政 府の公文書である「米国博覧会事務誌略」》を中心にアアメリカの 博覧会事務局による公式記録である「International Exhibition

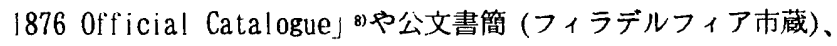
日本政府による英文の出品物リスト「Official Catalogue of the
Japanese Section」 9)、アメリカにおける数社の新聞記事などを参 考資料とした。

\section{1 博覧会参加の経緯}

日本の新政府による初参加の万国博は1873年のウィーン博であ る。しかし準備の遅れで、開会の前年まで参加を表明することが出 来なかったのに比べ、フィラデルフィア博への参加に関しては、す でに開会の3年前、1873年6月に日本政府はその意志をアメリカ側 に伝えている10。すなわち、フィラデルフィア博はウィーン博の経 験を生かし、十分に準備期間を設けて、より積極的に政府が出品物 の收集と展示に力を入れた成果が示されているといえる。

博覽会開催までの経緯を簡単にまとめてみた11)。

1871.3.3 アメリカの議会において、フィラデルフィアで独立百 年記念の国際的博覧会を開く法案が採択。

1873.6 アメリカ政府より日本に参加の勧誘があり、日本政府は 直ちに承諾。

1873.7.3 アメリカ大統領が博覧会開催を宣言。

1874.11公式な日本参加がワシントンの日本領事館からアメリ 力政府に伝えられる。

1875.1. 博覧会事務局が、新たに内務省の分局である勧業寮に 設置。

1875.4. 博覧会事務局の総裁に内務唧大久保利通、翌月副総裁 に陸軍中将西郷従道が任命される。

1875.6.12 博覧会事務官、関澤明清が在米事務のためアメリカへ

* 京都工芸繊維大学 大学院生

Graduate Student, Kyoto Institute of Technology 


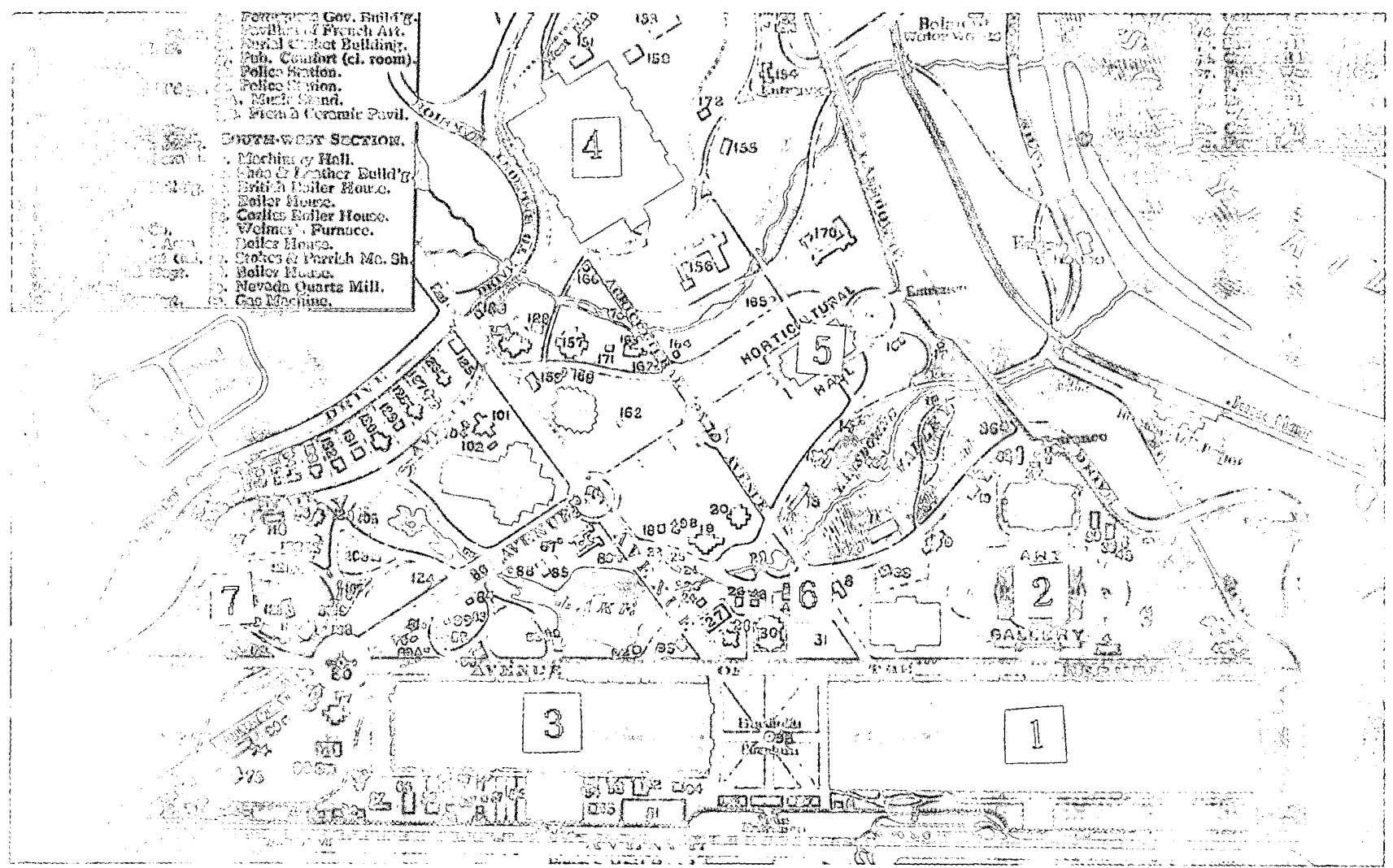

図-1 会場配置図「Map of Centennial Ground」『Centennial Portfolio」

(1) Main Building (2) Art Gallery (3)Machinery Building (4) Agricultural Building(5)Horticultural Building (6) Japanese Government (売店)

(7) Japanese Building (住宅家屋) ※このマップには売店がJapanese Governmentと記されている。

\section{発つ。}

1875.11.26日本から事務官らの渡航や出品物の運搬が始まる。8 23日までに合計3035箱が計16回の便（太平洋郵船会社） でアメリカへ運ばれる。

1876.3 事務官及び随行ら逐次フィラデルフィアに到着。 1876.5.10 開会

準備は大まかに二段階に分けられる。まず、博覧会参加の意志を 表明した1873年6月より5ヶ月後の11月にはワシントン駐在の全権公 使にその事務を行わせ、さらにウィーン博の博覧会事務官の一人が 準備に着手している。1874年12月には博覧会事務局から「米国博覧 会出品概則」123が出されている。これによると出品物の收集・買い 上け・展示・眅売がすべて官費で行われたウイーン博と異なり、今 回は自発的出品者も募るとし、希望者は1875年3月までに申し出、 政府の铨㚗・許可を得ることとある。また政府はこれとは別に各地 の有名工人の作品を直接買い上げて出品物としたが、その制作にあ
たって、図案指尊も行っている13。

第二段階は博覧会事務局が内務省に設置後、総裁や事弱官の正式 な任命が行われて急速に進む。特にウィーン博にも参加した関澤明 清がアメリカへ渡り直にアメリカ政府と交涉を行ったことは明記す ベさであろう。以上、フィラデルフィア博は、入念な準備と積極的 な日本政府の主導による参加であることがわかる。

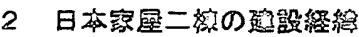

フィラデルフィア博は、フェアマウントパーク内236エイカーの 敷地を会場とし、合計194の建物が建てられた。そのうち主催国ア メリカの政府によるメイン会場は、本館（㫟ain Building）、アート ギャラリー(Art Gallery)、機械館 (Machinery Building)、農業館 (A gricultural Building)、園芸館(Horticultural Building)の五館 である(14)。

日本は表 1 に示したように、本館、農業館等に出品物を展示する

表-1主なアメリカ政府主催館の構成と日本の出品状況

\begin{tabular}{|c|c|c|c|}
\hline 建物 & 部 & 分穎番号 & 日本の出品 \\
\hline Main Building 本館 & 1. Mining and Metallurgy 独業 & $100 \sim$ & 244点 \\
\hline & 2. Manufactures 贸造業 & $200 \sim$ & 2458 点 \\
\hline & 3. Education and Science 教育と科学 & $300 \sim$ & 743点 売店、住宅家屋はこの部門に分穎された。 \\
\hline Art Gallery アートギャシリ- & 4. Art アート & $400 \sim$ & 展示は本館で行われた。 \\
\hline Machinery Building 機械館 & 5. Machinery 機械 & $500 \sim$ & 不明 ほとんど無しと思わ扎る。 \\
\hline Agricultural Building 農業館 & 6. Agriculture 農業 & $600 \sim$ & 771 点 \\
\hline Horticultural Building 園芸館 & 7. Horticulture 園芸 & $700 \sim$ & 387点 売店横の庭園に展示。 \\
\hline
\end{tabular}

『International Exhibition 1876 Official Catalogue』より作成 
をともに(5)、日本人の大エによる二棟の貄物を建設している。先に も触れたように、一棟は政府によるJapanese Bazaar(売店)であり、 もう一棟は金沢の土族、河村幸(')の出品によるJapanese Dwelling (住宅家屋)"である。

これらの建設経緯に触れておこう。1875年4月、すなわち博筧会 の約 1 年前、日本政府はアメリカ政府に対し次の 3 点の要求を提出 している。1.日本の展示エリアを現在の7290フィートから11520フ ィート位に増やす 2.ディスプレイはすべて日本人の手によって 行う 3. 展示品の販売の許可183。

ここでは売店の建設は具体的に出ていないが、日本政府の最大関心 事は、貿易振興にあり、博覧会での物品の販売は今後の貿易品の市 場動向を知る上で最重要課題であった。前回の1873年ウィーン博、 さらにその前の1867年パり博においても壳店の反響は大さかった事 から(日)、フィラデルフィア博でも売店建設は必須であったと思われ る。在米公使代理、矢野二郎に代わって在米事務を引き継いだ博覧 会事務官の関澤明清から届いた1875年7月18日付の電報には「博覧 会の即売場の用に供する日本式建築の屋宇を造営すべき許可を得 た」20とある。さらに8月27日付関澤からアメリカ政府への手紙"2に は展示の準備をする人のための宿舎を建てるスペースを要求、9月1 旧には許可をもらったお礼の言葉22)が述べられている。これらの 手紙から、政府が積極的にこの二つの日本家屋の建設を進めていた ことがわかる。

こうして9月にはアメリカ側の許可を得て、二棟の建設が決定し た。たたし住宅建築の方は、金沢の河村幸の志願があった為、この 建築は河村に任せられ、建築費用として五千円を政府が貸し付ける こととなっだ3。

1875年11月26日、フィラデルフィア博へ向けての第一便が出航す る。この太平洋郵船 (Pacific Mail Steam Ship Company) アラス 力号には建築用木材、瓦、その他の職工用品 387 トン事務官、事 務官随行、職人たちが乗り込んでいた241。

フィラデルフィアに赴き、二つの建築造営（庭園も含む）に関わ った人物を表一2に示した。

売店と住宅家屋の建設に携わった大工がそれぞれ異なっている が、これは先にも述べたとおり売店が政府による建設であるのに対 し、住宅家屋が民間の出品人による建設であるからと思われる。後
表-2 渡米した建築関係者人名表

\begin{tabular}{|c|c|c|c|c|c|}
\hline 役職ほか & 人名 & 出身 & 年齢 & 出航日 & 帰国日 \\
\hline 事预官随行 & 松尾伊兵衛 & 東京 & 42才2ヶ月 & 1875.11 .26 & 1876.7 .23 \\
\hline 同 & 宮城忠左衛門 & 東京 & 40才8ヶ月 & 1876.2 .23 & 1877.1 .24 \\
\hline 売店掛 大工職 & 熊本半兵衛 & 東京 & 44才10ヶ月 & 1875.11 .26 & 1876.7 .23 \\
\hline 同 & 関口善吉 & 千葉 & 37才10ケ月 & 1875.11 .26 & 1876.12 .26 \\
\hline 同 & 中野留吉 & 東京 & 40才11ヶ月 & 1875.11 .26 & 1876.7 .10 \\
\hline 同 & 石井吉五郎 & 東京 & $42 才$ & 1875.11 .26 & 1876.7 .10 \\
\hline 同 & 山下茂三郎 & 東京 & 33才7ヶ月 & 1875.11 .26 & 1876.7 .10 \\
\hline 売店掛 瓦莓職 & 高木辰之助 & 東京 & 31才8ヶ月 & 1875.11 .26 & 1876.7 .10 \\
\hline 旅店掛 大工職 & 山田孫三 & 石川 & 42才2ヶ月 & 1875.11 .26 & 1877.1 .23 \\
\hline 同 & 関根大五郎 & 埼玉 & 45才5ヶ月 & 1875.11 .26 & 1877.1 .23 \\
\hline 同 & 内山春次 & 新潟 & 23才5ヶ月 & 1875.11 .26 & 1876.7 .10 \\
\hline 同 & 石黒元吉 & 新潟 & $24 才$ & 1875.11 .26 & 1876.7 .10 \\
\hline 旅店掛 左官職 & 藤野音次郎 & 東京 & 26才11ヶ月 & 1875.11 .26 & 1876.7 .10 \\
\hline
\end{tabular}

P米国費拉特费府博覧会掛并出品人名表』より作成

者の担当の大工は北陸出身者が多いが、これは出品人、つまりは経 済的スポンサーである河村幸が石川県の士族であることから当地の 職人を集めた可能性が考えられる。

また、11月13日に事務官随行の拝命を受けた松尾伊兵衛25) は、 売店と住宅家屋の両方の建設に棟梁として携わった。もう一人の事 務官随行、宮城忠左衛門は売店の横に付随する庭園を担当した。松 尾と宮城の二人は 3 年前のウィーン博でも建築と庭園制作を行って いる28\%。建築資材はすべて日本から運んだものを使い27》、大工のほ か瓦莫職人や左官職人も渡航している。数枚のイラストによる作業

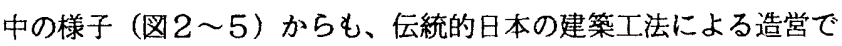
あることが推察できる。

\section{3 出品物としての建築}

日本の出品物の分類は、主催国アメリカの政府からあらかじめ届 いた、本館、アートギャラリー、機械館、農業館、園芸館の五館の 展示分類項目に従っている。これによると本館はさらに3つの部門 に分かれ、全部で7部門となっており、それぞれさらに細かい分類 が分類番号をつけて行われている。(表 1 参照)

さて、ここで問題にしている売店と住宅家屋は、どちらも第 3部 の「Education and Science」(教育と科学)に分類されている。さ らに細かい分類番号で示せば、第3部は300番台から始まっており、 342に住宅家屋，343に売店がそれぞれ分類された。アメり力側が規

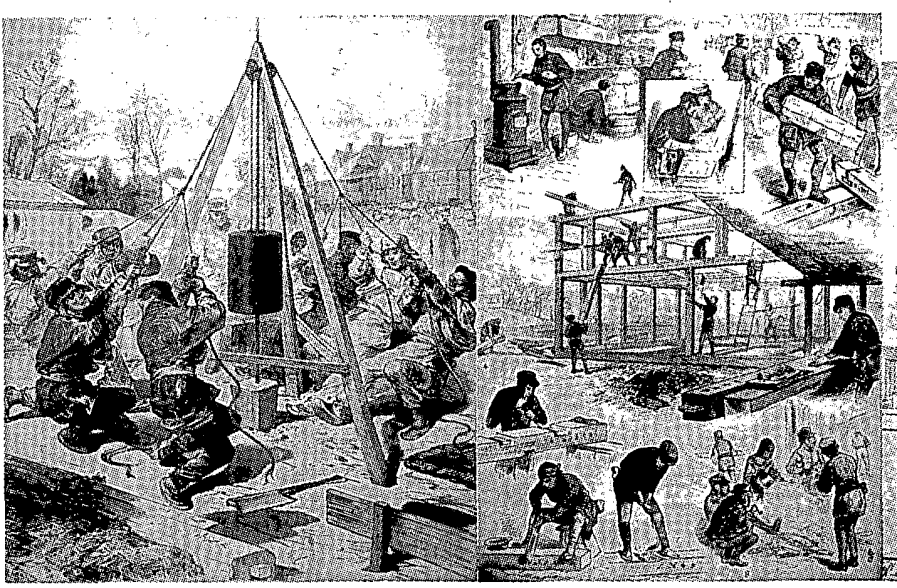

図- 2 作業風景
図-3 作業風景

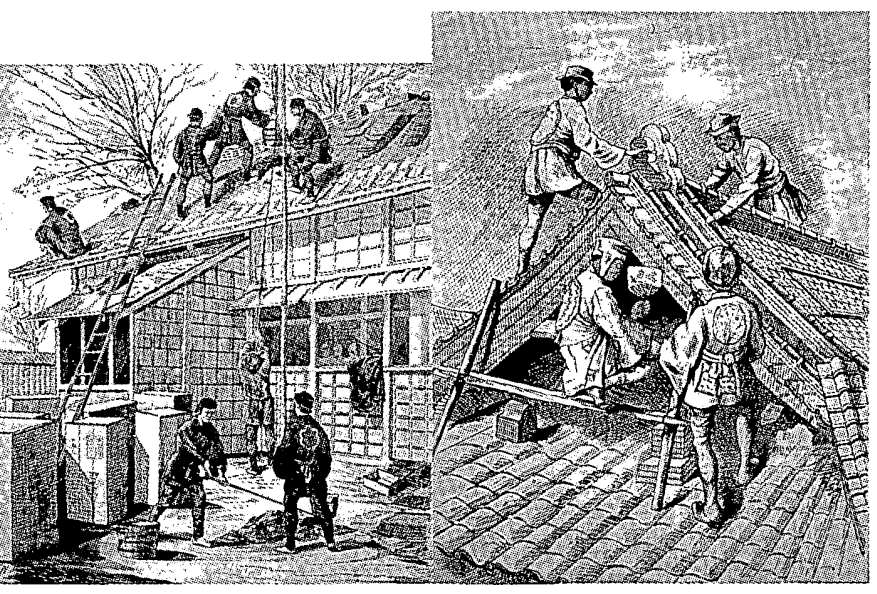

図- 4 作業風景

図- 5 作業風景

図 $2 \sim 5$ 『Frank Leslie's Illustrated Historical Register of Centennial Exhibition 1876』 
定した分類項目の内容は下記のとおり。また当時の翻訳も合わせて 付した。

rClass 342 The drelling. Sanitary conditions and regulations. Domestic architecture.-Drell ings characterized by cheapness, combined ith the conditions essential to health and comfort. Fire-proof structures. Hotels, club-houses, etc. Public baths. 1 )

「342 居家、保安/形状及七条例、鄙戝/住居、並二健全適决ノ 形状、火习防クヘキ築造、客舎、会宴所等、混屋」29

rClass 343 Commercial systems and appliances. Mercantile fo rms and methods, counting-houses and of fices... 130

「343 貿易二法式 及上使用物、商売ノ体裁、方法...」 ${ }^{31}$

要するに342では、住宅と住まい万、343では商売の方法、様子な どにおいて、各国、各地域の特性を展示、公開することを目的とし ている。日本はこれに応じて、住宅家屋、売店という形式をとりな がらむその建築意厈においては、日本を代表するものとしてふさわ しいと当時の価値観において判断されたスタイルで表現したのであ る。

さて、これらは出品物であるから審㚗の詨象となり、両者とも受 賞している。住宅家屋に関しては受賞者は「松尾伊兵衛 日本事務 官匠長」で、審㚗評には「木材ノ結構絶努・・屋背及七遊廊ノ配置 幽雅ニシテ瓦营モ亦善ク整列セり彫刻ノ装飾又美䩋ナり」 ${ }^{32)}$ とあ る。

売店と庭園は博㹂会後、アメリカ側の希望もあり政府へ贈与され るが、そのと先の表明文に次のようなくだりがある。「元来右売店 ノ義八旁物品売路ノ為而巳ニアラス日本建築/巧妙卜園庭位置ノ風

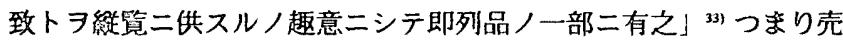
店はただ売るだけの場所ではなく、日本建築と庭園の巧妙さを見せ ることも主旨の一つである、と。さらにその建築の美しさはすでに 新聞でも称賛され、出品物の壳り上げにも貢献した、とある。

また、住宅家屋の利用状況等を調べてみると、次のことがわかっ た。まず、当初からここは渡航者の全員を收容するための宿泊所と して意図されたわけではない。事務官用の宿泊所としては前年の準 備段階で「フィラデルフィア市コロンビアアベニュー、北方バィヨ ラ町南42番丁/西」に搷瓦の建物をドビンス氏という人物に築造し てもらう約束を取り付け、明治9年1月1日より12月30日まで19室借 りることを決定しているが。日本を代表する政府官憶は、日本の文 明度の高さを示すた的にも宿泊には西洋スタイルが望まれたのであ ろう。(図13)

さらに宿泊だけでなく、事弱官のオフィスや外国人の接待にも利 用されていたようである35。博覧会の会期中、外国人の急な接待に 「壳店適有ノ器物 7 㷛 た、とある。つまり売店から適切な器物を借りて、日本家屋の室内 飾りの一例を示し、接待所としての役割も果たしたのである。

\section{4 管の泟管}

1876年早々から始まった日本人による建築作業は、アメリカ人に とって初めて見る珍しい光景であったため、新聞にたびたび揭載さ れた。ます職人のための仮設の小屋が建てられ、2月12日には地業 工事と思わ㧈る様子が、Frank Leslie's Illustrated Nerspaper ${ }^{3 n}$
の捜画（図2）に見られる。この様子は一般紙だけでなく、建筑の 専門紙The American Architect and Building Ners ${ }^{38}$ にも注目さ れ、「最も奇妙な作業...20フィートの高さの三脚を据え、頂点に二 つの滑車を付け、300ポンドの重さの円柱形の鉄の重りをロープで 支えている」38) と詳しく説明された。また、大工の使った道具や 木組みに関して 詳細に紹介した記事も、Scientific American Supplement 誌 (1876.3.11) に見られる。

住宅家屋の方は1.876年4月初めに落成し、13日から一部が事枒所 として使われている(9)。場所は西門近くのジョージヒルの西斜面。

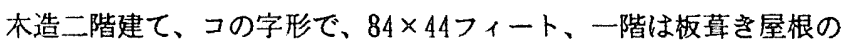
出格子、二階には外側が回廊となり手すりが付けられている。屋根

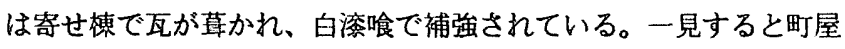
か旅籠風であり、玄関部にはやや反りのある千鳥破風の式台がつい ている。(図10.11)

前述の専門誌には「a most extraordinary structure」41) (最も 特異な楧造) と語され、釘を使っていないこと、シャッターのよう に壁が動くこと（雨戸や㐿、障子と思われる）、玄関のポーチ上部

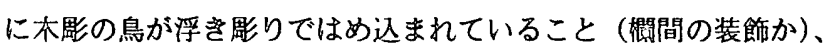
屋根はタイルのようなもので覆われていること、などが子細に述べ られている。内部の様子については写真や描かれた資粼が見つかっ ていないが、「奇怒なデザインの蒙華なカーペットが敷かれ、壁か らは植物の結維で編んだ、光を遮り、風を通すカーテンが下がって いる」42)とある。この描写よりおそらく瞢や穊が掛けられた室内 と推定される。

また売店は、6月5日付公信に尔いて「売店建設落成二付本月10日 開店」 ${ }^{43)}$ とあるので開会の1ヶ月後、6月10日にオープンした。会 場内の中央館と機械館の近く中央入り口付近に位置し、外锶は木造 平屋建て、コの字形の両翼が張り出し、入母屋造りの屋根、さらに 軒唐破風による構えとなっている。（図6.7.8）大きさは約 $125 \times 40$ フィートで、内部は北向等に壁や建具を設置せず、朋と机とカウン ターが置かれ、オープンなスペースとなっている。横には倉庫も付 随している44)

庭園は売店の東面、南面に設けられた。庭園の造営についてはア メリカ側の強い要請もあった ${ }^{45)}$ が日本政府側としても前回のウィ ーン博の例をあって問題は無かったと思われる。配置図（図9）か らみると正面に池があり、花壇のように区切られ、竹の穊でおおわ れている。石の灯籠や銅製の鶴なども置かれていた ${ }^{46}$ 。

\section{5 「两」の㴼出}

この二横の建筑にはいくつかの興味深い点が見られる。まず、住 宅家屋の玄関に付けられた千鳥破風の式台、そして、売店の両翼の 入母屋の屋根と軒唐破風であるい。式台は、近世武家屋敷に始まり、 後に貴族・寺家・町村役人さらに地主・豪商層などに広まる。つま り近世における社会的地位を、さらに近世杢には経済的地位をも示 す象徵であった。同様に唐破風ももともと寺社や武家屋敷に見られ るものである。

国内における近代和風建築の䅡型化に関してはすでに研究が進め

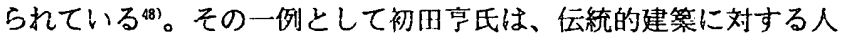
々の関わり方の連いという視点から、1 . 伝統的建築を継承するこ とに価値をみとめつつ、その発展を試みた［伝統の維持、発展]、 


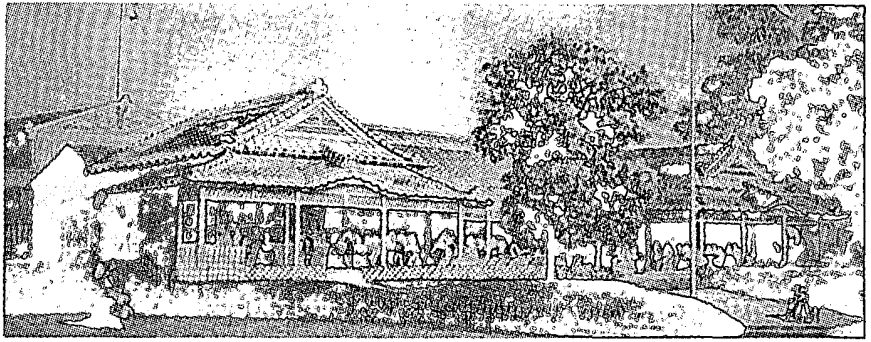

図-6 Japanese Bazaar（売店）『Centennial Portfolio』

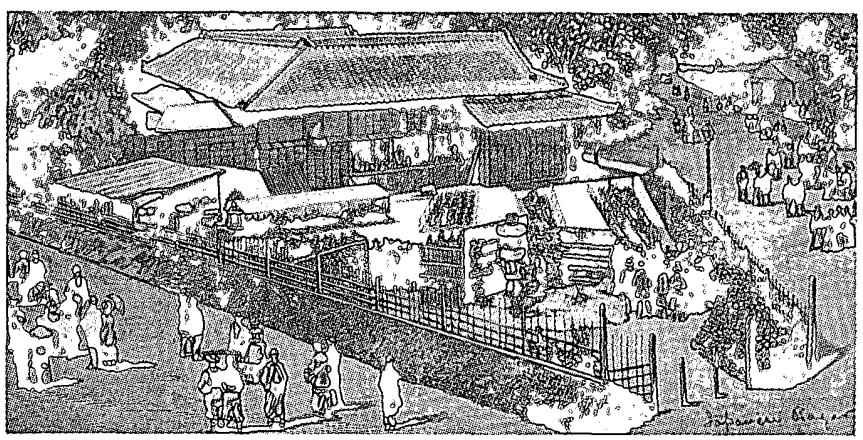

図-7 南から見たJapanese Bazaar 『Frank Leslie's Illustrated Historical Register of Centennial Exhibition 1876』

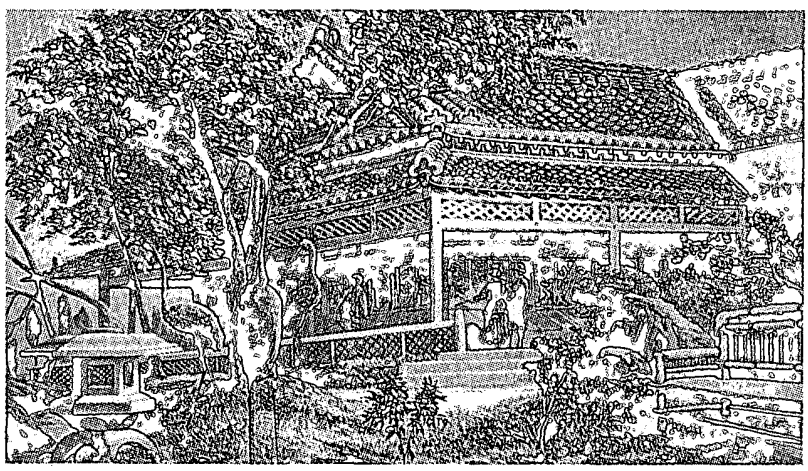

図-8 東から見たJapanese Bazaar（Free Library蔵）

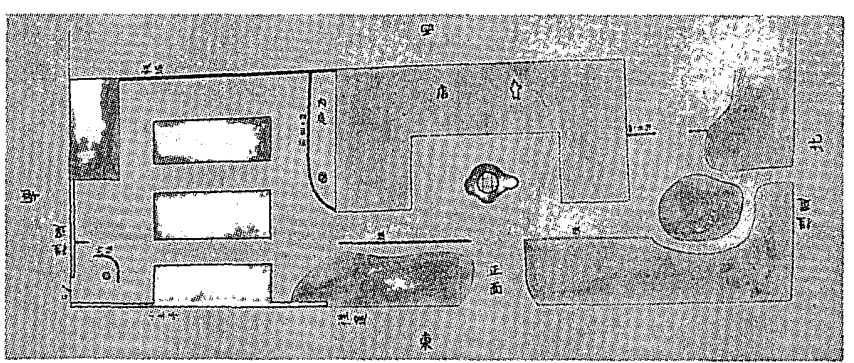

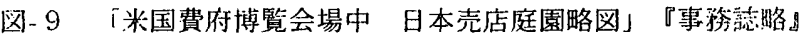

2.伝統的建築を構成する要素をばらばらに分解し、好みの要素の みを選ぶ傾向の見られる[要素の集積］3.日本的なるものにこだ わりながらもその生活様式や建築の構造には洋式化を取り入れ、新 しい様式をつくりたそうとする [和風の構築] と分類し、さらに2 [要素の集積] の中でもかつての社会的地位の象敒である唐破風の ような要素を取り込んだものを［豪華さへの指向］としている。

海外における博覧会での日本建築をこの分頑にあてはめるとした らどうだろうか。フィラデルフィアの場合、建築資材のすべてを日 本から運び込み、13人もの建築技術者が渡米していることからも、 あくまで伝統的工法と素材にこだわった［伝統の維持］の要素が強 いことがわかる。しかし、それたけけではなく、住宅家屋に式台をつ けたり、物品を販売する建物に唐破風をつけるところなどに、[豪 華さへの指向］が見られる。初田氏は［豪華さへの指向］は社会的

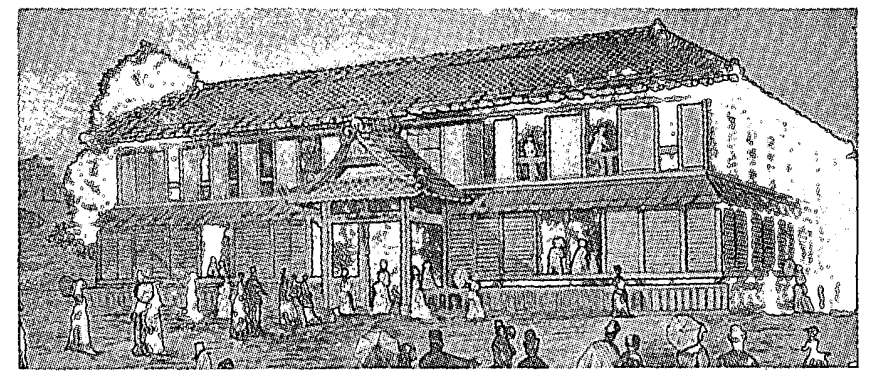

图-1 0 Japanese Dwelling（住宅家屋）『Centennial Portiolio』

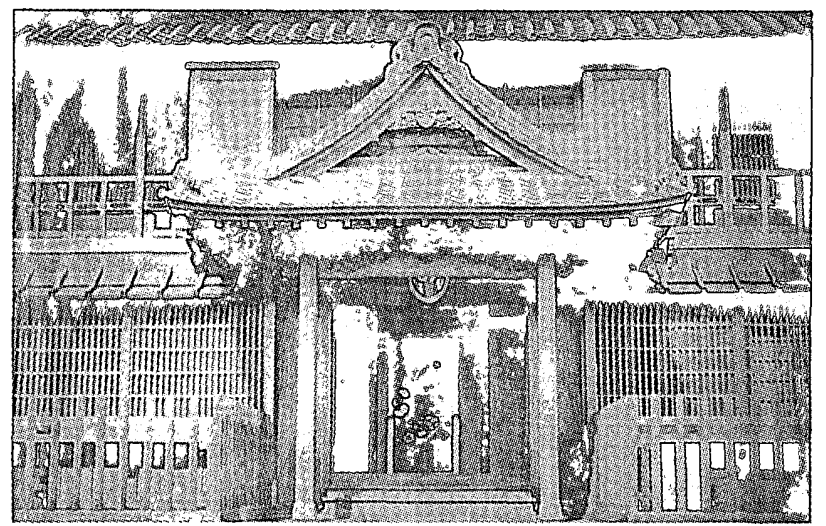

写真- 11 Japanese Dwelling の玄関部 (Free Library藏)

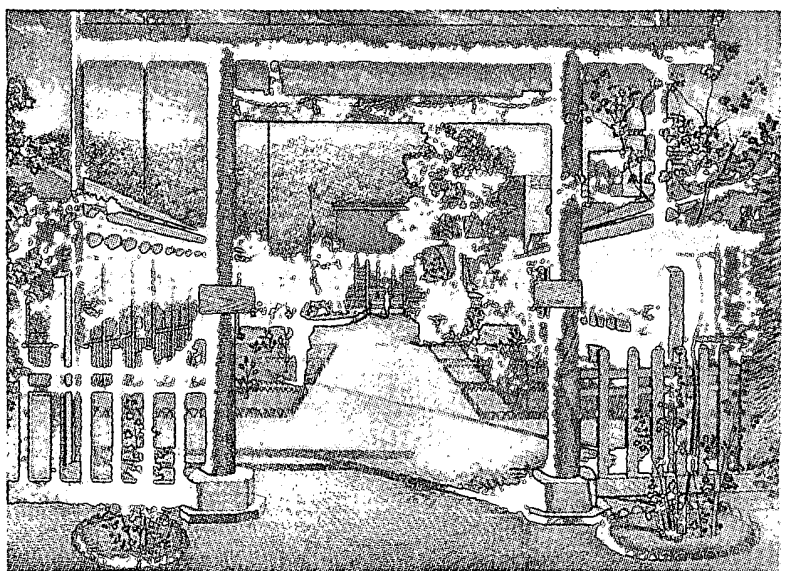

図-1.2 ウィーン博会場図『海外博覧会本邦参同史料』

地位を高めたいとする庶民や新興階級に多く建てられたとしてい る。博覧会においては外国において「日本」をアピールすべく、当 時においてある程度格式の高いという認識のある建築意匠が部分的 に付加されたのであろう。

明治9年といえば国内では盛んに洋風建築の導入・推進がはから れ、擬洋風建築も多数建設された時期である。海外の万博において はあえて日本の伝統的工法と様式で「日本であること」を表現しよ うとしたのではないか。そこに見られる意匠は、後のシカゴ博やそ れ以後の博覧会建築のように、過去の建築物に範を求めるのではな く、江戸後期の価值観をひきついでいることがわかる。つまり明治 初期の日本人が想定した「日本的なもの」をここにみることができ る。

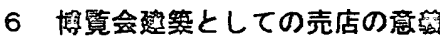

博覧会での二棟の建築のうち、政府が建造したのが売店の方であ ったことに注目したい。もちろん前述のように住宅家屋の方も建築 費用を政府が貸し付け、建築作業も実質的には政府の雇った大工と 
共に行っており 、政府の肝入れであることには間違いない。しか し、売店建設に政府は6038円19銭を支出しており、これは出品物の 買い上け于金の 合計1万5886円83銭に比較して大をな支出ともいえ る50)。政府が值接建設と展示や運営に関わった建物を「日本館」と するなら、この博覧会において日本館は売店という事になる。なぜ 政府はこれほどの支出をして、実際に事務所としても活用した住宅 家屋ではなく、売店を建設したのか。

この問題考えるうえで、先行する1873年のウィーン博につくら れた壳店に簡単に触れておきたい。この時政府はメーン館の䧆列と は別に1300坪の日本庭園には入口に白木の鳥居、その正面舆に神社 の社殷、脇に神楽堂が建てら机、鳥居から社殿までには $2 ， 3$ の売 店が作られた。これは神祭りの社前の市になぞらえたとあるら1)。図 12 によると提灯を吊り下げた左右二つの建物が売店と思われる。

この博覧会の出品物は手工芸品 ${ }^{52}$ )が多くを占的ていたが、これ が政付の期待以上に好評を博し、壳店での工芸品の売れ行齐もよか った。きた、売店では最終日に影絵のパフォーマンスも行われ注目 を集めた。すなわち壳店は「日本的」雾囲気を演出し、工芸品の質 売を促進する役割を果たしたのである。以後、政府は工芸品を主に 扱う商社、起立工商会社を設立し、重要翰出品の一つとしてその図 絮改良、制作、市場開拓などに力を注いでいく。さらに、博覧会後、 建築物と庭園はイギリスの商社アレクサンドルパークの要請を受 け、600ポンドで壳却されてロンドンに移築された。つきり建築物 そのものも貼売の対象となったのである。ウィーン博の成黑とこれ にもとづく今後の政策方針は、博覧会副総裁佐野常民の 34 冊にわた る報告青によって克明にレポートされ、後の博覧会に大学な影䈕を 与えた。

明治初期の日本は関䂱自主権の欠如を含む不平等条約や巨額の外

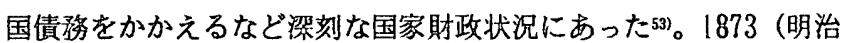
6年) 内務省の成立に伴い内務唧大久保利通は積極的な貿易振興政 策を打ち出していく。しかし、当時日本は幕圭までの鎖国により、 民間による対外通商関係が欠如しており、貿易を担う民間の資本の 蓞櫝がなかったため、政府が直翰出そのものを実質的に代行せざる をえなかった54。

このような政府主導の貿易振興策の柱になったのが博覧会であっ た。ウィーン博の博覧会突務所は、当初太政官正院におかれていた が、博覧会後は博物館と名称を变えて内務省の所管となり、フィラ デルフィア博のそれは、内務省の中でも犆産與業政策の要となった 勧業察に置かれている。博覧会における壳店が、政府にとって貿易 のための市場調豈としての重要な位置を占めていたことは明らかで あろう。

ウィーン博では出品物の収集から買い上け゚、運営に至るきですべ て政府によるものであったが、フィラデルフィア博においては、政 府の収管・買い上けによる出品とは別に民間の出品も行っている。 をちろん河村の例でも見たように出品者には政府が資金を貸し付け ており、展示場の他売店でも販売を行わせ、週ごとに収益金を計算 して、貸付金の返済に充てるようにさせていた。

壳店を直接博覧会事務所が建築・運営する例は、フィラデルフィ ア博以後見あたらない汭が、おそらく民間の貿易商社がしだいに成 長していく明治後期ころまでは何らかの形で政府が支援していたと 思われる5゙。

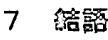

背上、国内外で行った資料調亘をもとに、フィラデルフィア博に おける建筑の分析によって以下のことが明らかになった。きず二轵 の建築は、出品物として日本建築の様式で建てられたこと、またそ れらは政府の直接または出資によって建設され、政拊の意向が強く 反映されていること。そこには武家屋数や寺社の要素が見られるこ と。さらにその形態は売店であっても、政府の貿易振興政策にもと づく重要な位置を占めていたことである。

博覽会における建築物は仮設的で特知なものとみなされているせ いか、建築史においてまだ十分に位置づけられていないように思わ れる。「博覽会の日本館はだいたいがちゃちである。..古い日本風 に見えればそれで良いという姿勢すら見受けられる。」57とする見 方もある。しかし少なくとも明治初期においては本論でみたように、 赤字財政の中での膨大な支出や13人もの建築関係者が渡米した事実 から、経済的にも人為的にも国家規模で最大の力を注いでいたこと がわかる。

藤岡・漂谷両氏581\}、日本政府又は政府より運営を委託された民 間団体による建物を「日本館」としたうえで、「茶室や売店などを 除けば、明治26（1893）年より前には日本関係の建物は事実上建設 されていないとし、考察の対象として茶室や売店を含めていない。 売店が「日本館」から除かれたのは、売店が博覧会の付随的存在で 主たる建筑ではないという現在の一般的通念が働いていたと思われ る。しかしフィラデルフィア博における「売店」は政府主導によっ てつくられ、殖産興業政策を背景に「日本館」ともいえる重要な位 置を占めていたことがわかる。

また、19世紀の博覧会が、各参加国による帝国主荃を背景とした 自国の工業と文化レベルの高さを誇示するステージであった59)こ とを考えるるき博覧会場に建てられた建造物もまた、すべてが見 られることを意識して作られた展示物であったといえるだろう。事 実この二槙の建築物は、それでれ物品販売や宿泊という機能を持台

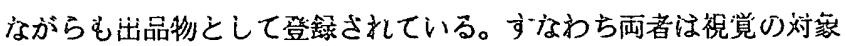
物として存在しているのであり、そのため政府に 1 日本的であるこ と」を表現しようという意識が働いていたことがうかがえる。

建築における「日本的なもの」への意識はいつごろ生まれたのだ ろうか。明治本に我が国の建築様式の論㦈が盛んとなり、その中で 「日本趣梏」の語が多用される600。しかし、建築に限らず美術、工 芸等も含めてその意識はもう少し早いと思われる。これについては 初田亭氏が1871（明治4）年から翌年にかけて建設された三茾組の 神戸の建築絵図面に見られる用語を通じて「日本的なもの」の意識 を指摘している811。日本という国家のアイデンティティは、開国後 西欧との接触によってその認識が促されたといえるが、この時期か ら、西欧に対しての「和風」「和椓」が生学れたのであり、「日本的 なもの」とは何か、という問いに直面したのである。

その最初の機会は、海外における万国博覧会であった。「日本的 なもの」の系譜を考えるうえで万国博覧会はひとつの事例として重 要であることは、すでに触れた先行の研究でも明らかである。

さらに、19世紀から20世紀にかけてめまぐるしく変化した口本国 内の情勢や国際関係を考えると、博覧会に現れる「日本的なもの」 は变化しており、決して一様ではない。今後も各博覧会における日 本の建築物や出品状況を、その政治・経済的背景をも含めてさらに 
詳しく調査するとともに、それらの比較分析を通して「日本的」要 素についての考察を重ねることを課題としたい。

\section{謝辞}

本論の資料調查にあたり、フィラデルフィア美術館の東アジア部 キュレイターFelice Fisher博士、同館りサーチャー木下京子氏に 多大なご協力をいただきました。ここに記して深謝申し上げます。

註

1) 藤岡洋保・樑谷康生「戦前に海外で開かれた国際博覧会の日本館の和風 意匠について」『日本建築学会計画系論文報告集』(1991.1)，三島雅博「189 3年シカジ万国博における鳳凰殿の建設経䋨について」『同報告集』(1991.11) 「鳳凰殿の形態とその成立要因について」『同報告集』(1992.4)「1900年パ リ万国博に扝ける日本館の形態について」『同報告集』(1993.8)，坂本久子 「アメリカ人がみたフィラデルフィア博覧会の日本館」『日本建築学会大会 学術講演梗概集』(北海道1995. 8)

2）坂本氏の前掲講演には多少の資料が提示されている。

3）藤岡・梁谷氏の前掲論文の中でフィラデルフィア博の建造物の主催が「米 国博覧会事務局」となっていたが、これは日本の博覧会事務局と民間である ことが本調查で明らかになった。また、吉見俊哉氏は『博覧会の政治学』(中 央公論社1992)の中で「旅館風の日本館と日本庭園のついた数寄屋風の建筑」 (p208)と述べているが本調査では数寄屋風建築は認められなかった。

4）1876年以前アメリカに扔てて1853年ニューヨーク、1871年サンフラン シスコにおいて博覧会が開催されているが、いずれも小規模で日本からの参 加もわずかしか譛ぬられない。

5) Clay Lancaster, 『The Japanese Influence in Anerica』1983 (初版196 3） p. 58 /ヴ他やト・珈リー『アメリカの建築とアーバニズム (上)』香山 寿夫訳、鹿島出版会 1973, p. 171

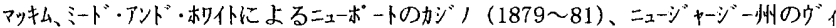
クター・ニュー汃胝 $(1880 \sim 81)$ 等が例として举げられる。

6） 1876-77年発行。第一〜五。以下『報告書』と記寸。

7) $1873-1877$ (明治6 10) 年の記録。第一〜七と付録。「記録材料」所収。以

下「事務誌略」と記す。

8) United States Centennial Commission発行 1876年

9) The Japanese Commission 発行 1876年，1300部が現地で印刷された。

10) 『 Official Catalogue of J. S. 』p. 3

11）「海外博覧会本邦参同史料」第 1 号. 1928年,「事務誌略」，

『official Catalogue』より作成

12）「海外博覧会本邦参同史料」第 1 号， p. 85

13）政府指導による図案に関しては近年、東京国立博物館においてその図案 集『温知図録』が発見された。同博物館発行の調查研究報告書「温知図録」 （1997.3）と『明治デザイの誕生』(国書刊行会，1997.4)に詳しい。

14) Pofficial Catalogue』

15）日本側で第 4 部アートに分類したものは現地の都合で中央館に展示、第 7 部園芸は売店横に展示される。第 5 部機械は展示されたかどうか不明。結 局日本は中央館と農業館の二館での展示が確認されている。

16) 石川県士族出身、詳細は不明。

17）「事務誌略」ほか日本側の資料には、この建物は「旅舎」「旅館」「旅店

「日本家屋」等と称されているが、本論内では便宜上「住宅家屋」とした。 18）当時の在米公使代理、二等書記官の矢野二郎からアメリカ政府八宛てた 公信 (Philadelphia City Archives 藏)

19）ウィーン博に関しては「一日の売上澳貨 2.3 千ゴルデンに達し...扇 ・団扇の如きは一週日間に数千本を壳尽せり」(海外博筧会本邦参同史料) とある。

20)「事務誌略二」明治8年7月18日の項

21）関澤明清からアメリカ政府への公信 (Philadelphia City Archives 蔵)

22) 21 と同し

23）「事務誌略二」明治8年9月8日の項

24)「事務誌略四」明治9年2月20日の項

25）松尾伊兵衛以下職人たちの出自については未詳。松尾は農業館に眖竹を 自沸にて出品しており (『official Catalogue of J. S. 』)これは原価380 円で、実際には2233円49銭で売却されている。(『報告書』第二「出品原価表」) 26）田中芳男・平山成信編「澳国博覧会参同記要」1897年 p. 37，松尾と宮 城はウィーン博においてそれぞれ建築術、園庭築造の技術伝習者のリストに も加的っている。(平山成信『昨夢録』大正14年 p. 121)

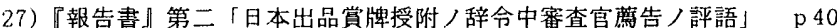

28) 『official Catalogue』

29）「費府博覧会分類略表」1876年
30) Pofficial Catalogue』

31）「費的博覧会分類略表」1876年

32)『報告害』第二「日本出品常牌授附ノ辞令中箇查官蔍告/評語」 p 35

33)「事務誌略」明治 9 年11月8日の項

34)「事務誌略二」明治8年9月6日の項。1タ月の家賃は1216ドル。

35) 「事務誌略二小明治8年9月6日の項

36)「事務誌略二」明治9年7月1日の項

37）19世紀半ば頃からニューヨークで発刊。フィラデルフィア博の際は会 場内に事務所を設け博覧会の様子を細かく伝えた。その内容は 1 冊にまとめ られ『Frank Leslie's Illustrated Historical Register of the Centenni al Exhibition1876』上して1877年に出版。

38）1876年1月1日にボストンで㓣刊。この年、フィラデルフィア博を機に多 くの新開、雑誌が創刊されたがそのうちの一つ。建築に対する関心の高まり をうかがうことができる。

39)「The Japanese at the Centennial」1876年2月12日付。

40)「事務誌略 付録」明治 9 年 4 月 18 日の項

41) The American Architect and Building News 「Japanese architecture」 1876年4月22日付。

42) Thompson Westcott 『Centennial Portfolio』Philadelphia; Thomas Hunter Publisher, 1876 p. 22

43）「事務誌略五」明治9年7月 22 日の項

44）T. Westcott 前揭書 p. 50 なお Tea House も付随し.ていたとClay Lancaster は述べているが、(「前掲書p. 48) 茶室の存在と形態は明らかで はない。扔そらく、数寄屋造りの茶室ではなく、単に日本の茶を供する場が あったと推測される。

45）「事務誌略二」明治8年7月25日の項には関澤から電信で、日本式住家及 び売店には必ず遊園を造るという米側の規則に従って造営すべきとある。

46）植物は以下の通り。[常青の樹木、海木] 松各種、七バ各種、杉、茶樹、

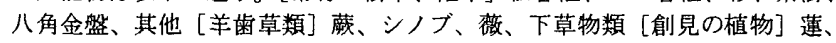
水草、水苔 [園庭の器具] 各種裁花、盈花架等 [飾用線工］竹製の藩籍、門 屝、策管 [園庭作造] 園庭花壇、石及石灯篁の配置（出品分類番号法、7 00 ７33）（「海外博覧会本邦参同史料」第一号 p 102）

47）干鳥破風や唐破風に对するアメリカ人の反応としてgrotesqueという表 現も見られるが (T. Westcott，前揭害 p. 50)、このインパクトは大きかっ たようで、後に暖炬の装飾などのモチーフとして取り入れられている例もあ る。(二1-3-ク, Dr. E. H. William の日本の部屋/ C. Lancaster, 前掲書 p. 55) 48）初田亨「近代和風建築入門」村松賁次郎 - 近江栄編『近代和風建築』所 収, 鹿島出版会 1988年

49） 2 章で耐建築の担当の大工は、リスト上に扔てて別々に名前が載ってい るとしたが、作業風景のイラストや竣工時期のずれから実際には共同で作業 したと考えられる。

50）「米国博覧会事務局経費出納表」発行年不明 1877 年頃か。この資料によ ると、派出費27万5376円 36 銭之採集費10万円を合わせた計37万5376円 36 銭が 支出費、これに対し計 26 万5 5410 円69銭7厘が収入となっている。

51）「海外博覽会本邦参同史料」第一号 p. 44-45，な招井上章一氏は「日本 館のエキソチシズム」『図説万国博覧会史1851-1942』吉田光邦稨，思文閣 出版1985）の中で「数寄屋風の茶室」としているが、笔者が調べた資料から はその存在は認められなかった。

52）横㴖広子「ウィーン万国博覧会出品目録草稿」『美術研究』357号，1994 53）拙稿「明治期の工芸品をめぐる輸出振興政策について」『賀茂文化研究』 第5号, 1997

54）大久保利通は明治7年「殖産興業に関守る建議書」の中で政府主導に上 る殖産興業の推進を表明。また、明治 8 年大隈重信とともに「輸出品习以于 外債償却ノ儀二付伺」の中で内務省忤業寮に扔いて積極的に政府貿易の推進 を図り、外借に充てるべきだとしている。

55) 藤岡・梁谷, 前掲論文 p. 102-103

56）例えば明治11年パリ博では売店を起立工商会社が建設・運営しているが 同社は政府が多大な出資をしている半官半民の会社である。

57) 井上，前掲書

58) 藤岡・深谷, 前揭論文

59）吉見，前掲書

60）川道麟太郎・橋寺知子「明治期に抢汀る「日本趣味」といら用語につい て」『日本建築学会計画系論文報告集』(1992.2)，藤岡洋保「明治・大正期の 日本の建築界における「日本的なもの」」『日本建築学会大会学術講演梗概集』 (近畿昭和62.10)

61)初田亭「近代和風建築 序文」初田亨 - 大川三雄 - 藤谷陽悦著 『近代和 風建築一伝統を超えた世界』建築知識, 1992 /拙稿「明治10年代の輸出工芸 品にみる日本イメージの創出」『デザ仅理論』35, 1996.この研究において少 なくとも明治10年代前半には既に美術工芸品に日本的イメージを付して輸出 しようとする政曻の意図を明らかにした。

*原资料の引用に摂いては旧字は新字に改めた。また英文資料からの翻訳は 笔者による。

（1997年 5 月 10 日原稿受理， 1997年 9 月 5 日採用決定） 